\title{
PERAN OJK DALAM MELINDUNGI PEMEGANG MEDIUM TERM NOTES MELALUI PENERBITAN POJK NOMOR 30 TAHUN 2019
}

\author{
Jordy Herry Christian, Fakultas Hukum Universitas Negeri Semarang, \\ E-mail: jordy31798@students.unnes.ac.id \\ Kirana Edenela, Fakultas Hukum Universitas Negeri Semarang, \\ E-mail: kedenela @gmail.com
}

doi: https://doi.org/10.24843/KS.2020.v08.i09.p02

\begin{abstract}
Abstrak
Tulisan ini mengkaji mengenai peran OJK dalam melindungi pemegang Medium Term Notes melalui penerbitan Peraturan OJK Nomor 30 Tahun 2019 dengan menggunakan pendekatan penelitian yuridis normatif. Hal yang akan dikaji adalah latar belakang OJK menerbitkan Peraturan OJK Nomor 30 Tahun 2019 yang mengatur mengenai efek bersifat utang dan/atau sukuk tanpa penawaran umum, yang salah satu contoh bentuknya adalah Medium Term Notes. Selain itu melalui tulisan ini, penulis juga akan mengkaji perbedaan pengaturan Medium Term Notes setelah ditetapkannya Peraturan OJK Nomor 30 Tahun 2019. Setelah mengkaji menggunakan pendekatan terhadap peraturan terkait, diketahui bahwa penetapan Peraturan OJK Nomor 30 Tahun 2019 adalah sebagai payung hukum guna mewujudkan kepastian hukum bagi pemegang Medium Term Notes untuk meminimalisir kasus gagal bayar seperti yang terjadi di SNP Finance. Perbedaan pengaturan penerbitan Medium Term Notes melalui POJK Nomor 30 Tahun 2019 secara jelas terlihat melalui hadirnya OJK dalam kewajiban pelaporan penerbitan Medium Term Notes dan adanya kewajiban pemeringkatan yang dilakukan oleh penerbit Medium Term Notes. Selain itu hadirnya peran Penata Laksana Penerbitan dan Agen Pemantau memberi dampak positif dalam mewujudkan asas keterbukaan guna realisasi dari Good Corporate Governance Principle.
\end{abstract}

Kata Kunci: Medium Term Notes; OJK; Peraturan

\begin{abstract}
This paper examines the role of Financial Fervices Authority in protecting Medium Term Notes holders through the issuance of Financial Fervices Authority Regulation No. 30 of 2019 using a normative juridical research approach. The matter to be examined is the background of Financial Fervices Authority issuing Financial Fervices Authority Regulation Number 30 of 2019 which regulates debt and/or sukuk securities without through public offering, one of the examples is Medium Term Notes. In addition, through this paper, the author will also examine differences in the regulation of the Medium Term Notes after the stipulation of Financial Fervices Authority Regulation Number 30 Year 2019. After examining using the approach to related regulations, it is known that the stipulation of Financial Fervices Authority Regulation Number 30 Year 2019 is as a legal umbrella in order to realize legal certainty for holders of Medium Term Notes to minimize default cases like SNP Finance. The difference in the arrangement of the issuance of the Medium Term Notes through Financial Fervices Authority Regulation Number 30 of 2019 is clearly seen through the presence of the Financial Fervices Authority in the reporting obligations of the issuance of the Medium Term Notes and the existence of the rating obligation performed by the issuer of Medium Term Notes. Besides that, the presence of the role of the Publishing Management and Monitoring Agent has a positive impact in realizing the principle of openness for the realization of the Good Corporate Governance Principle.
\end{abstract}

Keywords: Medium Term Notes; Financial Fervices Authority; Regulation 


\section{Pendahuluan}

\subsection{Latar Belakang Masalah}

Pasar keuangan yang terbagi menjadi pasar modal dan pasar uang memiliki perkembangan yang pesat seiring dengan perkembangan instrument yang bervariasi. Pasar modal merupakan wahana yang penggalangan dana jangka panjang yang disalurkan ke sektor sektor produktif dari himpunan dana masyarakat. Pasar modal sering dianggap sebagai salah satu sarana yang efektif guna mempercepat pembangunan suatu negara. ${ }^{1}$ Perkembangan pasar modal yang signifikan membuat banyak variasi instrument efek yang diperjualbelikan. Keberagaman tersebut meliputi perbedaan dari waktu jatuh tempo, tingkat risiko fluktuatif bunga maupun kepastian jaminan dari masing-masing efek. Salah satu jenis efek yang diminati masyarakat adalah efek bersifat utang yang memiliki kelebihan, yaitu memiliki risiko yang relatif lebih rendah dibandingkan instrumen efek lainnya seperti saham dan lebih menjamin kepastian keuntungan yang diperoleh. Adapun dilansir dari Indonesia Stock Exchange (IDX), contoh jenis efek bersifat utang yang saat ini tercatat di bursa adalah obligasi korporasi, sukuk, Surat Berharga Negara yang terbagi menjadi Surat Utang Negara dan Surat Berharga Syariah Negara serta Efek Beragun Aset (EBA). Obligasi korporasi adalah surat utang yang diterbitkan oleh korporasi atau perusahaan guna memenuhi kebutuhan dana pembiayaan yang dibutuhkan. ${ }^{2}$ Tetapi seiring perkembangan, investor mulai memilih Medium Term Notes (Surat Utang Jangka Menengah) dibandingkan obligasi dikarenakan kelebihan yang dimiliki Medium Term Notes (MTN). Salah satu contoh pembeda antara keduanya adalah obligasi bisa diterbitkan oleh negara melalui pemerintah pusat maupun pemerintah daerah dan perusahaan swasta, sedangkan Medium Term Notes hanya dapat diterbitkan oleh perusahaan swasta atau korporasi. ${ }^{3}$

Kelebihan dari Medium Term Notes antara jangka waktu pembayarannya yang lebih fleksibel yaitu antara 5 sampai 10 tahun dan penerbitannya lebih mudah dibandingkan obligasi karena tidak memerlukan tahapan penawaran umum dipasar modal serta prosedur penerbitan yang lebih mudah daripada obligasi. ${ }^{4}$ Prosedur yang lebih mudah dalam penerbitan Medium Term Notes oleh perusahaan adalah karena tidak adanya kewajiban untuk meminta izin dari Otoritas Jasa Keuangan dalam penerbitannya. Padahal sejatinya Medium Term Notes tidak terlepas dari risiko seperti risiko gagal bayar oleh perusahaan penerbit Medium Term Notes kepada investor. Risiko gagal bayar penerbit Medium Term Notes diperburuk dengan absennya peran Otoritas Jasa Keuangan (OJK) dalam meregulasi penerbitan Medium Term Notes di Indonesia. Penerbitan Medium Term Notes tidak diatur dengan ketentuan yang spesifik membuat kepastian hukum dan perlindungan terhadap pemodal atau investor tidak dapat direalisasikan. Menyadari hal tersebut, OJK selaku lembaga pengawas di industri jasa keuangan yang memiliki kewenangan untuk membuat peraturan dalam sektor keuangan menerbitkan Peraturan Otoritas Jasa Keuangan, yaitu POJK Nomor

${ }^{1}$ Rokhmatussa'dyah, Ana \& Suratman. Hukum Investasi \& Pasar Modal (Jakarta: Sinar Grafika, 2017).

2 Wahyuningdyah, Kingkin. "Sistem Hukum Dalam Penerbitan Dan Perdagangan Commercial Paper," Yustisia 4, no. 3 (2015): 700-717.

${ }^{3}$ Kamarga, Rosalina Oktavia Kamarga, "Tanggung Jawab Penerbit Obligasi Terhadap Investor Dalam Hal Gagal Bayar Menurut Ketentuan Hukum Pasar Modal," E-Journal Graduate Unpar 1, no. 2 (2014): 74-80.

${ }^{4}$ Mudjiyono, "Investasi Dalam Saham \& Obligasi Dan Meminimalisasi Risiko Sekuritas Pada Pasar Modal Indonesi," Jurnal STIE Semarang 4, no. 2 (2012): 1-18. 
30/POJK.04/2019 tentang Penerbitan Efek Bersifat Utang dan/atau Sukuk yang Dilakukan Tanpa Melalui Penawaran Umum pada tanggal 29 November 2019. POJK mengenai efek bersifat utang dan/atau sukuk (EBUS) tanpa penawaran umum ini yang menjadi payung hukum guna merealisasikan kepastian hukum dan memberikan perlindungan terhadap pemodal atau investor Medium Term Notes.

\subsection{Rumusan Masalah}

Berdasarkan uraian dari latar belakang diatas, maka penelitian ini akan membahas:

1. Mengapa OJK memperketat penerbitan Medium Term Notes oleh korporasi melalui POJK No.30 Tahun 2019?

2. Bagaimana perbedaan pengaturan penerbitan Medium Term Notes pasca penetapan POJK No.30 Tahun 2019?

\subsection{Tujuan Penulisan}

Tujuan dari penulisan ini adalah mengetahui latar belakang pengetatan penerbitan Medium Term Notes dan perbedaan pengaturan penerbitan Medium Term Notes pasca penetapan POJK Nomor 30 Tahun 2019.

\section{Metode Penelitian}

Metode yang digunakan adalah pendekatan statue approach atau metode yuridis normatif. Dengan metode penulisan ini, peraturan yang akan digunakan adalah peraturan yang terkait dengan tema pembahasan yaitu penerbitan Medium Term Notes, sehingga dalam hal ini dasar hukum yang digunakan adalah Peraturan OJK sebagai data primer, yaitu POJK Nomor 30 Tahun 2019. Selain itu terdapat tambahan literasi lainnya yang penulis gunakan, seperti jurnal-jurnal yang terkait dengan tema artikel sebagai data sekunder untuk mengetahui alasan yang mendasari OJK memperketat penerbitan Medium Term Notes oleh korporasi melalui POJK Nomor 30 Tahun 2019 dan perbedaan pengaturan penerbitan Medium Term Notes pasca penetapan POJK Nomor 30 Tahun 2019.

\section{Hasil dan Pembahasan}

\subsection{Alasan OJK Memperketat Penerbitan Medium Term Notes Melalui Pojk Nomor 30 Tahun 2019}

OJK mempunyai tugas pengaturan dan pengawasan dalam sektor pasar modal. Sebagai realisasi dari tugas pengaturan dan pengawasan guna melindungi konsumen dan masyarakat di sektor pasar modal, OJK pada tanggal 29 November 2019 menetapkan sebuah produk hukum yaitu Peraturan OJK No. 30 Tahun 2019 yang digunakan sebagai payung hukum bagi pemodal atau konsumen Efek bersifat utang dan/atau Sukuk (EBUS) tanpa penawaran umum. Penetapan POJK No.30 Tahun 2019 merupakan cerminan dari penegakan kepastian hukum di Indonesia selaku negara hukum (rechtstaat). Terdapat beberapa alasan lainnya yang membuat OJK memutuskan untuk memperketat penerbitan Efek bersifat utang dan/atau Sukuk tanpa penawaran umum melalui penerbitan peraturan-peraturan terhadap Efek bersifat utang dan/atau Sukuk yang dilakukan tanpa penawaran umum, yaitu:

1. Praktik penerbitan Efek bersifat Utang dan/atau Sukuk yang dilakukan tanpa melalui Penawaran Umum masih belum memiliki pengaturan dan pengawasan Sebelum lahirnya Otoritas Jasa Keuangan melalui UU Nomor 21 tahun 2011, BAPEPAM-LK adalah yang berwenang mengawasi, mengatur dan membina 
kegiatan pasar modal. Pasca penetapan UU Nomor 21 tahun 2011, kewenangan BAPEPAM-LK dialihkan kepada OJK, sehingga pengaturan mengenai surat utang sebagai efek pasar modal yang tenor waktunya melebihi satu tahun merupakan kewenangan OJK dalam hal mengatur, membina dan mengawas. Medium Term Notes merupakan bentuk efek bersifat utang yang memiliki masa tenor melebihi satu tahun, sehingga kedudukan Medium Term Notes dalam Pasar Modal berada dalam ruang abu-abu yang tidak jelas pengaturan, pembinaan dan pengawasannya dilakukan oleh Bank Indonesia atau OJK setelah penetapan UU Nomor 21 Tahun 2011.

Pengaturan dan pengawasan terhadap efek bersifat utang dan/atau sukuk (EBUS) yang dilakukan tanpa melalui penawaran umum merupakan hal yang penting dan tepat untuk dilakukan. Di satu sisi, melalui penerbitan POJK No.30 Tahun 2019 selaku payung hukum, pemodal Efek bersifat utang dan/atau sukuk yang dilakukan tanpa melalui penawaran umum selaku konsumen mendapatkan bentuk perlindungan hukum dan kepastian hukum. Di satu sisi lainnya, penerbitan POJK No.30 Tahun 2019 dilatarbelakangi juga oleh beberapa kasus gagal bayar Medium Term Notes (salah satu contoh EBUS tanpa melalui penawaran umum), sebagai contoh adalah PT Sunprima Nusantara Pembiayaan (SNP Finance) yang berpolemik pada tahun 2018..$^{5}$ Bercermin dari kasus gagal bayar oleh penerbit Medium Term Notes sebelum adanya Peraturan OJK Nomor 30 Tahun 2019 merupakan bentuk ketidakmampuan OJK melindungi konsumen atau pemegang Medium Term Notes, hal ini dikarenakan kewenangan pengawasan secara langsung tidak dimiliki oleh OJK, sehingga penerbitan Medium Term Notes pada praktiknya tidak memerlukan izin dan laporan penyampaian kepada OJK. Dikarenakan recht vacuum ini, banyak pemegang Medium Term Notes yang dirugikan karena kasus gagal bayar yang salah satunya diakibatkan karena tidak adanya peran OJK dalam penerbitan Medium Term Notes. Medium Term Notes juga merupakan surat berharga yang memiliki ciri mudah dialihkan, sehingga pemindahtanganan dapat dengan mudah dilakukan terhadap Medium Term Notes yang mengakibatkan pemegang Medium Term Notes kesulitan dalam melakukan pengalihan piutang yang akan merugikan pemegang Medium Term Notes selaku pembeli. ${ }^{6}$

2. Melaksanakan kesepakatan negara-negara G20 pada tahun 2008 dalam Declaration Summit on Financial Markets and The World Economy

Indonesia selaku anggota G20 yang berkomitmen melaksanakan kebijakankebijakan dalam pasar keuangan sepakat untuk menerapkan Enhancing Sound Regulation, yang pada isinya berbunyi:

"We pledge to strengthen our regulatory regimes, prudential oversight, and risk management, and ensure that all financial markets, products and participants are regulated or subject to oversight, as appropriate to their circumstances. We will exercise strong oversight over credit rating agencies, consistent with the agreed and strengthened international code of conduct. We will also make regulatory regimes more

5 Saragih, Elvandi Christian ,Budiharto \& B. ,Siti Malikhatun. “Akibat Hukum Putusan Pailit Terhadap Pemegang Medium Term Notes (MTN) (Kasus PT. Sunprima Nusantara Pembiayaan)," Diponegoro Law Journal 8, no. 2 (2019): 1042-1060.

6 Sutedi, Adrian. Aspek Hukum Obligasi Dan Sukuk (Jakarta: Sinar Grafika, 2009). 
effective over the economic cycle, while ensuring that regulation is efficient, does not stifle innovation, and encourages expanded trade in financial products and services. We commit to transparent assessments of our national regulatory systems."

Secara singkat Indonesia selaku anggota G20 berkomitmen untuk memastikan terdapat regulasi yang mengatur mengenai semua produk maupun pelaku pasar keuangan. Efek bersifat utang dan/atau sukuk yang diterbitkan tanpa melalui penawaran umum merupakan salah satu contoh produk yang belum diregulasi dalam sektor pasar modal. Kepastian hukum merupakan hal yang sangat penting untuk direalisasikan guna memberikan perlindungan dan kepastian terhadap pemegang Medium Term Notes selaku pemodal dari masyarakat, oleh karenanya OJK menetapkan POJK No.30 Tahun 2019 untuk mengisi kekosongan hukum tersebut.

Perlindungan hukum terhadap investor atau pemegang Medium Term Notes merupakan hal yang senyatanya belum ada sebelum ditetapkannya Peraturan OJK Nomor 30 Tahun 2019 dikarenakan peraturan terhadap penerbitan Medium Term Notes sebatas peraturan umum dalam KUHD dan KUHPer. Ketiadaan peraturan yang secara khusus mengatur mengenai penerbitan Medium Term Notes membuat perlindungan dari kasus gagal bayar tidak dapat direalisasikan dan diminimalisir. Perlindungan terhadap pemegang Medium Term Notes sebelum adanya Peraturan OJK Nomor 30 Tahun 2019 didasarkan pada kesepakatan antara penerbit dan pemegang Medium Term Notes yang dituangkan dalam perjanjian Medium Term Notes. Penjaminan terhadap Medium Term Notes secara umum dijaminkan kepada harta kekayaan perusahaan penerbit Medium Term Notes, sehingga membuat kedudukan pemegang Medium Term Notes hanya sebagai kreditur biasa yang tidak memiliki hak istimewa dalam pelunasan apabila terjadi kasus gagal bayar yang dilakukan oleh emiten selaku penerbit Medium Term Notes.

Selain itu, penerbitan Medium Term Notes yang tidak mewajibkan adanya pemeringkatan juga memicu terjadinya banyak kasus gagal bayar. Padahal sejatinya pemeringkatan terhadap efek bersifat utang seperti obligasi dan commercial paper adalah wajib dilakukan pemeringkatan guna menjadi suatu acuan bagi investor atau pemegang Medium Term Notes untuk menentukan tingkat keberhasilan penjualan dari efek bersifat utang (seperti Medium Term Notes) khususnya di pasar perdana. ${ }^{7}$ Pemeringkatan merupakan hal yang penting untuk diwajibkan dalam penerbitan Medium Term Notes karena pemeringkatan tersebut menilai kemampuan serta kemauan emiten selaku penerbit Medium Term Notes untuk memenuhi kewajibannya ketika sudah jatuh tempo, sehingga kasus gagal bayar dapat diminimalisir dengan adanya kewajiban melakukan pemeringkatan sebagai bentuk pengawasan terhadap penerbitan Medium Term Notes. Adapun contoh lembaga pemeringkat yang ada di Indonesia adalah PT. Pemeringkat Efek Indonesia yang sudah diakui oleh OJK.

\subsection{Perbedaan Pengaturan Penerbitan Medium Term Notes Pasca Penetapan Pojk Nomor 30 Tahun 2019}

Hubungan hukum para pihak dalam perjanjian jual beli Medium Term Notes adalah bentuk pinjam meminjam atau verbruiklening, dikarenakan karakteristik dari

7 Fataruba, Sabri. “Tinjauan Yuridis Terhadap Surat Utang Jangka Pendek (Commercial Paper) Sebagai Salah Satu Alternatif Pembiayaan Melalui Perdagangan Surat Berharga," Jurnal Sasi 17, no. 4 (2011): 28-38. 
Medium Term Notes itu sendiri yang merupakan efek bersifat utang. ${ }^{8}$ Sehingga terhadap hubungan antara penerbit dan pemegang Medium Term Notes masih terikat pada ketentuan-ketentuan dalam Buku III Kitab Undang-Undang Hukum Perdata dan ketentuan dalam Kitab Undang-Undang Hukum Dagang tentang Surat Sanggup (Order), karena Medium Term Notes dapat dikategorikan sebagai surat berharga. ${ }^{9}$ Sebelum ditetapkannya Peraturan OJK Nomor 30 Tahun 2019, pengawasan terhadap penerbitan Medium Term Notes secara langsung bukan kewenangan OJK. Dalam Pasal 1 ayat (5) dan Pasal 70 ayat (2) Undang Undang Pasar Modal, dijelaskan bahwa terdapat beberapa jenis efek yang merupakan kewenangan BAPEPAM-LK dan yang bukan kewenangan BAPEPAM-LK (sebelum adanya OJK melalui UU Nomor 21 tahun 2011, BAPEPAM-LK adalah yang berwenang mengawasi, mengatur dan membina kegiatan pasar modal). Setelah adanya OJK, kewenangan BAPEPAM-LK, surat utang sebagai efek pasar modal yang memiliki tenor waktu dibawah satu tahun seperti Commercial Paper merupakan kewenangan Bank Indonesia dan terhadap surat utang sebagai efek pasar modal yang tenor waktunya melebihi satu tahun merupakan kewenangan OJK dalam hal mengatur, membina dan mengawas. ${ }^{10}$ Medium Term Notes berada dalam ruang abu-abu yang tidak jelas pengaturan, pembinaan dan pengawasannya dilakukan oleh Bank Indonesia atau OJK setelah penetapan UU Nomor 21 Tahun 2011. Sehingga pengaturan mengenai Medium Term Notes sebelum ditetapkannya Peraturan OJK Nomor 30 Tahun 2019 adalah mengikuti peraturan dalam Kitab Undang-Undang Hukum Dagang Indonesia dalam Pasal 174, 175, 176 dan 177 mengenai surat sanggup (order) dan Kitab Undang-Undang Hukum Perdata khususnya bagian pinjam meminjam atau verbruiklening. ${ }^{11}$

Pasca penerbitan dan penetapan Peraturan OJK Nomor 30 Tahun 2019, terdapat beberapa pengaturan mengenai efek bersifat utang dan/atau sukuk (EBUS) yang diterbitkan tanpa melalui penawaran umum. Adapun di dalam penjelasan pasal 4 POJK Nomor 30 Tahun 2019 menyebutkan contoh bentuk dari EBUS tanpa penawaran umum, yaitu Medium Term Notes, Medium Term Notes syariah dan obligasi surat berharga perpetual.12 Sehingga Peraturan OJK Nomor 30 Tahun 2019, tidak hanya terbatas pada pengaturannya terhadap Medium Term Notes saja. Adapun dalam Peraturan OJK pasal 3 ayat (1) menyebutkan bahwa, ruang lingkup yang termasuk kriteria EBUS tanpa penawaran umum, yaitu efek bersifat utang dan/atau sukuk yang memiliki waktu jatuh tempo melebihi satu tahun dan juga nilai penerbitannya adalah Rp.1.000.000.000,00 atau yang memiliki nilai kurang dari Rp.1.000.000.000,00 tetapi penerbitannya dilakukan beberapa kali dalam jangka waktu satu tahun dan nilai totalnya mencapai satu miliar rupiah. Selain terhadap efek bersifat utang dan/atau sukuk tanpa penawaran umum yang memiliki jatuh tempo melebihi satu tahun, pada

8 Putridewi, Rosi Nani. "Karakteristik Perjanjian Jual Beli Medium Term Notes," Hukum Bisnis 3, no. 1 (2019): 1-20. 1996).

9 Setiadi, A. Obligasi Dalam Perspektif Hukum Indonesia (Bandung: Citra Aditya Bakti,

10 Prabowo, Bimo Adi \& Setiawati, Wenny. “Tinjauan Yuridis Urgensi Diperlukan Pengaturan Untuk Penerbitan MTN (Medium Term Notes) Dan Perlindungan Investor Pemegang MTN Di Indonesia" (2015).

11 Subekti. Pokok Pokok Hukum Perdata (Jakarta: PT. Intermasa, 2005).

12 Ramli, Muhammad Alpian. "Perlukah Medium Term Notes Diatur OJK?," HukumOnline.Com, last modified 2020, accessed June 6, 2020, https://www.hukumonline.com/berita/baca/lt5e706e4e550f7/perlukah-medium-term-notesdiatur-ojk-oleh--muhammad-alpian-ramli?page=all. 
pasal 3 ayat (2) nya menyebutkan bahwa EBUS yang memiliki jatuh tempo tidak lebih dari 1 (satu) tahun yang tidak diawasi oleh otoritas lain dan juga nilai penerbitannya adalah Rp.1.000.000.000,00 atau yang memiliki nilai kurang dari Rp.1.000.000.000,00 tetapi penerbitannya dilakukan beberapa kali dalam jangka waktu satu tahun dan nilai totalnya mencapai satu miliar rupiah termasuk kedalam kriteria EBUS tanpa penawaran umum yang diatur dalam Peraturan OJK Nomor 30 Tahun 2019.

Adapun ketentuan yang wajib dipenuhi oleh Medium Term Notes (salah satu bentuk EBUS tanpa penawaran umum) dalam penerbitannya berdasarkan pasal 4 ayat (1) Peraturan OJK Nomor 30 Tahun 2019 adalah:

1. Medium Term Notes wajib diterbitkan dalam bentuk tanpa warkat atau scripless, sehingga mekanisme penyimpanannya adalah secara elektronik;

2. Medium Term Notes wajib disimpan di lembaga penyimpanan dan penyelesaian (LPP) yang disimpan dalam bentuk penitipan kolektif kepada Bank Kustodian, dan saat ini fungsi LPP dijalankan oleh KSEI (PT Kustodian Sentral Efek Indonesia);

3. Penerbitan Medium Term Notes oleh pihak selain emiten wajib melakukan pemeringkatan dengan nilai paling sedikit 100\% dari nominal Medium Term Notes tersebut, guna mengukur kemampuan penerbit Medium Term Notes untuk memenuhi kewajiban pembayaran secara tepat waktu;

4. Pembelian kembali Medium Term Notes hanya dapat dilakukan setelah satu tahun dari tanggal penerbitan Medium Term Notes tersebut;

5. Pemegang Medium Term Notes tidak melebihi 49 pihak dan pemindahbukuan paling sedikit Rp.25.000.000,00 atau kelipatannya.

Emiten dan pihak lain selain emiten, dalam menerbitkan Medium Term Notes wajib melakukan pemeringkatan. Pemeringkatan tersebut wajib dilakukan oleh perusahaan pemeringkat efek yang telah memperoleh izin dari Otoritas Jasa Keuangan. Sedangkan untuk lembaga supranasional, pemeringkatan dapat dilakukan oleh lembaga pemeringkat internasional seperti Standard \& Poors dan Moody's. Setelah melakukan pemeringkatan dan mendapatkan hasil pemeringkatan tersebut, penerbit Medium Term Notes memiliki kewajiban untuk menyampaikan kelengkapan dokumen Medium Term Notes yang tercantum dalam pasal 4 ayat (2) dalam jangka waktu paling lama satu tahun.

Pihak yang dapat menerbitkan Medium Term Notes berdasarkan Pasal 6 Peraturan OJK Nomor 30 Tahun 2019, yaitu: emiten; badan usaha atau badan hukum di Indonesia selain emiten; lembaga supranasional; atau kontrak investasi kolektif. Sedangkan pihak yang dapat membeli Medium Term Notes berdasarkan pasal 7 adalah pemodal profesional yang memenuhi kriteria dalam formulir pemesanan Medium Term Notes ketika melakukan pembelian Medium Term Notes dari penerbit. Pernyataan sebagai pembeli profesional dilakukan oleh pihak yang akan melakukan pembelian, yang pernyataan tersebut disampaikan kepada penerbit atau Penata Laksana Penerbitan (arranger). Pihak yang memastikan bahwa pihak pembeli merupakan pemodal profesional adalah Perantara Pedagang Efek / pialang saham/ broker (apabila perdagangan dilakukan melalui perantara pedagang efek) dan Kustodian (apabila perdagangan dilakukan tanpa perantara efek). Apabila pihak pembeli bukan termasuk kedalam pemodal professional, Perantara Pedagang Efek wajib menolak instruksi beli dan Kustodian wajib menolak instruksi pemindahbukuan.

Peran Penata Laksana Penerbitan (arranger) dalam penerbitan Medium Term Notes dicantumkan dalam pasal 10 Peraturan OJK Nomor 30 Tahun 2019. Penerbitan 
Medium Term Notes wajib menggunakan Penata Laksana Penerbitan yang sudah memiliki izin kegiatan usaha dari Otoritas Jasa Keuangan sebagai penjamin emisi efek dari OJK. Adapun tugas-tugas yang wajib dilaksanakan oleh Penata Laksana Penerbitan, yaitu: membantu pihak penerbit dalam proses penerbitan Medium Term Notes dan memastikan pihak pembeli Medium Term Notes (pembeli profesional) sudah membaca memorandum informasi dan dokumen terkait dengan keterbukaan informasi sebelum melakukan pemesanan Medium Term Notes.

Selain Penata Laksana Penerbitan (arranger), penerbitan Medium Term Notes juga wajib menggunakan Agen Pemantau sesuai amanat pasal 12 Peraturan OJK Nomor 30 Tahun 2019. Agen Pemantau yang terlibat dalam proses penerbitan Medium Term Notes wajib merupakan pihak yang terdaftar sebagai wali amanat di OJK. Dalam melakukan kegiatan pemantauan Medium Term Notes, Agen Pemantau wajib bertindak independen dan dilarang untuk: mempunyai hubungan afiliasi dengan penerbit; menerima dan meminta pelunasan atas kewajiban penerbit kepada Agen Pemantau selaku kreditur; merangkap selaku penanggung dan/atau pemberi agunan dalam penerbitan Medium Term Notes. Tugas yang wajib dilaksanakan oleh Agen Pemantau antara lain adalah: memantau pelaksanaan kewajiban penerbit berdasarkan perjanjian yang berkaitan dengan pemegang Medium Term Notes; memberitahukan pemegang Medium Term Notes apabila terdapat kelalaian atau pelanggaran perjanjian \& keadaan yang membahayakan kepentingan pemegang Medium Term Notes; secara berkala melakukan analisa dan pemantauan terkait perkembangan pengelolaan usaha penerbit; serta memberikan kepada Lembaga Penyimpanan dan Penyelesaian semua keterangan yang diminta.

Prosedur dan tata cara dalam menerbitkan Medium Term Notes berdasarkan Pasal 15, Pasal 16 dan Pasal 17 Peraturan OJK Nomor 30 Tahun 2019 adalah:

1. Pra Penerbitan Medium Term Notes

Pihak penerbit Medium Term Notes wajib menyampaikan dokumen penerbitan Medium Term Notes kepada OJK yang ditujukan kepada Kepala Eksekutif Pengawas Pasar Modal. Adapun isi dari dokumen penerbitan Medium Term Notes berdasarkan pasal 18 adalah surat pengantar atas penerbitan Medium Term Notes dan memorandum informasi (rincian informasi factual yang jelas dan komunikatif tanpa informasi yang menyesatkan)

Dokumen penerbitan Medium Term Notes yang disampaikan kepada OJK wajib berbentuk cetak dan terdapat salinan elektronik yang memuat informasi yang sama dengan informasi yang tercantum dalam bentuk cetak dari dokumen penerbitan tersebut Sebelum menyampaikan kepada OJK, terdapat beberapa ketentuan yang harus diperhatikan, yaitu apabila penerbit membutuhkan persetujuan dari regulator, maka Penerbit Medium Term Notes wajib mendapatkan persetujuan dari regulator sebelum menerbitkan Medium Term Notes. Dan apabila penerbit Medium Term Notes adalah emiten, kontrak investasi kolektif atau menerbitkan Medium Term Notes hanya kepada reksa dana berbentuk investasi kolektif penyertaan terbatas, dokumen penerbitan Medium Term Notes wajib disampaikan oleh penerbit, sedangkan apabila penerbit Medium Term Notes adalah selain pihak yang disebutkan, maka dokumen penerbitan Medium Term Notes wajib disampaikan oleh Penata Laksana Penerbitan yang bertindak untuk dan atas nama penerbit Medium Term Notes. 
2. Penerbitan Medium Term Notes

Setelah menyampaikan dokumen penerbitan Medium Term Notes yang dibutuhkan kepada OJK dalam bentuk cetak maupun salinan elektronik, pihak penerbit wajib menerbitkan Medium Term Notes tersebut dalam jangka waktu 30 hari sejak dokumen penerbitan Medium Term Notes disampaikan.

3. Pasca Penerbitan Medium Term Notes

Apabila penerbit ingin melakukan perubahan terhadap isi dokumen penerbitan Medium Term Notes, maka dokumen tersebut wajib disampaikan kembali kepada OJK yang memenuhi ketentuan yang sama dengan penyampaian dokumen penerbitan Medium Term Notes sebelumnya.

Peraturan OJK Nomor 30 Tahun 2019 juga mewajibkan penyampaian laporan hasil penerbitan Medium Term Notes yang dilakukan oleh pihak penerbit kepada OJK dalam bentuk cetak dan salinan elektronik yang memuat informasi yang sama dengan bentuk cetaknya. Laporan hasil penerbitan Medium Term Notes wajib disampaikan paling lama 5 hari kerja setelah dilakukan penerbitan Medium Term Notes dalam bentuk dan isi yang sesuai dengan format laporan hasil penerbitan EBUS tanpa penawaran umum dalam lampiran POJK Nomor 30 Tahun 2019. Berdasarkan pasal 41 Peraturan OJK Nomor 30 Tahun 2019, penyampaian laporan tidak terbatas kepada penerbit, tetapi juga meliputi semua pihak yang melakukan transaksi Medium Term Notes yang dalam hal ini termasuk juga pihak pembeli Medium Term Notes yaitu pembeli profesional yang wajib menyampaikan laporan atas setiap transaksi efek kepada OJK.

Penerbitan Medium Term Notes berdasarkan Peraturan OJK Nomor 30 Tahun 2019 dapat dilakukan secara bertahap, berdasarkan pasal 33, penerbitan bertahap dapat dilaksanakan dalam periode dua tahun yang pemberitahuan pelaksanaan penerbitan bertahap disampaikan kepada OJK paling lama pada tahun kedua sejak penyampaian dokumen penerbitan Medium Term Notes tahap pertama kepada OJK dan pemeringkatan terhadap penerbitan berkala harus mencakup keseluruhan nilai penerbitan. Terhadap penerbitan bertahap, ketentuan penyampaian laporan penerbitan Medium Term Notes kepada OJK juga dilaksanakan paling lama 5 hari kerja sejak penerbitan Medium Term Notes oleh pihak penerbit.

Dengan penerbitan dan penetapan Peraturan OJK Nomor 30 Tahun 2019, terdapat beberapa kelebihan yang dirasakan mendukung pemenuhan aspek keterbukaan dan Good Corporate Governance Principle dari penerbit Medium Term Notes sebagaimana yang diamanatkan dalam Undang-Undang Pasar Modal. ${ }^{13}$ Pengaturan yang mendukung aspek keterbukaan dan Good Corporate Governance Principle tersebut terdapat dalam ketentuan yang mengharuskan pencantuman memorandum informasi yang memuat semua informasi penerbit kepada OJK dan pembeli Medium Term Notes. ${ }^{14}$ Pengaturan mengenai kewajiban pelaporan oleh Agen Pemantau dalam pasal 14 Peraturan OJK Nomor 30 Tahun 2019 juga merupakan bentuk positive dengan mendukung aspek keterbukaan dalam penerbitan Medium Term Notes kepada pemegang Medium Term Notes. Ketentuan yang mengandung asas

13 Sili, Eduardus Bayo. "Perlindungan Investor Obligasi Di Pasar Modal Melalui Pendekatan Etika Bisnis Bagi Penerbit Obligasi," Jurnal Hukum E Pembangunan 46, no. 2 (2016): 196-213. 2014).

14 Nasarudin ,M. Irsan, et al. Aspek Hukum Pasar Modal Indonesia (Jakarta: Kencana, 
keterbukaan dalam Peraturan OJK Nomor 30 Tahun 2019 merupakan upaya untuk meningkatkan akuntabilitas pengelola emiten, sehingga tingkat kepercayaan pemegang Medium Term Notes dan masyarakat semakin tinggi dikarenakan dengan adanya sikap akuntabilitas, penerbit Medium Term Notes mencerminkan mematuhi peraturan terkait dan merupakan indikator etika yang dimiliki oleh emiten. ${ }^{15}$ Sehingga realisasi kepastian hukum dan perlindungan pemegang Medium Term Notes semakin nyata dengan ketentuan-ketentuan mengenai Medium Term Notes dalam Peraturan OJK Nomor 30 Tahun 2019 guna menghindari risiko yang merugikan pemegang Medium Term Notes.

\section{Kesimpulan}

Lahirnya Peraturan OJK Nomor 30 Tahun 2019 yang memperketat proses penerbitan Medium Term Notes dilatarbelakangi oleh beberapa alasan yang bertujuan untuk melindungi konsumen atau pemegang Medium Term Notes dan memenuhi amanat Declaration Summit on Financial Markets and The World Economy yang menyatakan bahwa pasar uang, produk dan pihak yang terlibat di dalamnya harus diatur dalam suatu regulasi. Alasan lain yang membuat OJK memperketat penerbitan Medium Term Notes adalah dipicu oleh banyaknya kasus gagal bayar yang terjadi setelah Medium Term Notes telah jatuh tempo dan emiten tidak dapat melaksanakan kewajibannya. Hal ini didasari karena tidak adanya peran OJK dalam pengawasan dan pengaturan terhadap Medium Term Notes, serta tidak adanya kewajiban pemeringkatan terhadap Medium Term Notes yang menyebabkan tidak dapat diminimalisirnya kasus gagal bayar. Sebagai upaya menanggulangi hal tersebut dan mewujudkan kepastian hukum, OJK menerbitkan payung hukum berupa POJK Nomor 30 Tahun 2019 yang mengatur mengenai efek bersifat utang dan/atau sukuk yang salah satu contoh bentuknya adalah Medium Term Notes. Perbedaan pengaturan mengenai Medium Term Notes pun jelas terlihat setelah penerbitan POJK Nomor 30 Tahun 2019 yang berlaku mulai tanggal 01 Juni 2020. Diantaranya adalah hadirnya peran Agen Pemantau dan Penata Laksana Penerbitan yang berperan dalam penerbitan Medium Term Notes guna mewujudkan asas keterbukaan melalui kewajiban penyampaian memorandum informasi kepada pembeli Medium Term Notes selaku pembeli profesional. Peran OJK pun hadir dalam penerbitan Medium Term Notes baik Medium Term Notes biasa maupun Medium Term Notes bertahap setelah diberlakukannya POJK Nomor 30 Tahun 2019, yaitu adanya kewajiban pelaporan yang wajib dilakukan oleh pihak penerbit Medium Term Notes. Dengan ketentuan-ketentuan dan kewajiban sebagaimana ditulis dalam POJK Nomor 30 Tahun 2019, peran OJK dalam mengawasi penerbitan Medium Term Notes semakin merealisasikan amanat aspek keterbukaan dalam Undang-Undang Pasar Modal guna melindung pemegang Medium Term Notes selaku konsumen dan pemodal dari masyarakat.

15 Setiawan, Yudhi. "Peranan Dan Tanggung Jawab Perusahaan Pemeringkat Efek Dalam Melakukan Pemeringkatan Efek Surat Utang Di Indonesia," 2011. 


\section{Daftar Pustaka}

Buku

Nasarudin, M. Irsan, Indra Surya, Ivan Yustiavandana, Arman Nefi, and Adiwarman. Aspek Hukum Pasar Modal Indonesia. Jakarta: Kencana, 2014.

Rokhmatussa'dyah, Ana, and Suratman. Hukum Investasi \& Pasar Modal. Jakarta: Sinar Grafika, 2017.

Setiadi, A. Obligasi Dalam Perspektif Hukum Indonesia. Bandung: Citra Aditya Bakti, 1996.

Subekti. Pokok Pokok Hukum Perdata. Jakarta: PT. Intermasa, 2005.

Sutedi, Adrian. Aspek Hukum Obligasi Dan Sukuk. Jakarta: Sinar Grafika, 2009.

\section{Jurnal}

Kamarga, Rosalina Oktavia. “Tanggung Jawab Penerbit Obligasi Terhadap Investor Dalam Hal Gagal Bayar Menurut Ketentuan Hukum Pasar Modal." E-Journal Graduate Unpar 1, no. 2 (2014): 74-80.

Mudjiyono. “Investasi Dalam Saham \& Obligasi Dan Meminimalisasi Risiko Sekuritas Pada Pasar Modal Indonesi." Jurnal STIE Semarang 4, no. 2 (2012): 1-18.

Putridewi, Rosi Nani. "Karakteristik Perjanjian Jual Beli Medium Term Notes." Hukum Bisnis 3, no. 1 (2019): 1-20.

Sabri Fataruba. "Tinjauan Yuridis Terhadap Surat Utang Jangka Pendek (Commercial Paper) Sebagai Salah Satu Alternatif Pembiayaan Melalui Perdagangan Surat Berharga." Jurnal Sasi 17, no. 4 (2011): 28-38.

Saragih, Elvandi Christian, Budiharto, and Siti Malikhatun B. "Akibat Hukum Putusan Pailit Terhadap Pemegang Medium Term Notes (MTN) (Kasus PT. Sunprima Nusantara Pembiayaan)." Diponegoro Law Journal 8, no. 2 (2019): 1042-1060.

Sili, Eduardus Bayo. "Perlindungan Investor Obligasi Di Pasar Modal Melalui Pendekatan Etika Bisnis Bagi Penerbit Obligasi." Jurnal Hukum E Pembangunan 46, no. 2 (2016): 196-213.

Wahyuningdyah, Kingkin. "Sistem Hukum Dalam Penerbitan Dan Perdagangan Commercial Paper." Yustisia 4, no. 3 (2015): 700-717.

\section{Skripsi \& Thesis}

Prabowo, Bimo Adi, and Wenny Setiawati. "Tinjauan Yuridis Urgensi Diperlukan Pengaturan Untuk Penerbitan MTN (Medium Term Notes) Dan Perlindungan Investor Pemegang MTN Di Indonesia" (2015).

Setiawan, Yudhi. "Peranan Dan Tanggung Jawab Perusahaan Pemeringkat Efek Dalam Melakukan Pemeringkatan Efek Surat Utang Di Indonesia," 2011.

\section{Website}

Ramli, Muhammad Alpian. "Perlukah Medium Term Notes Diatur OJK?" HukumOnline.Com. Last modified 2020. Accessed June 6, 2020. https://www.hukumonline.com/berita/baca/lt5e706e4e550f7/perlukahmedium-term-notes-diatur-ojk-oleh--muhammad-alpian-ramli?page=all. 